\title{
ANL/MSD/CP-100799
}

\section{Temperature Dependence of Ion Irradiation Induced Amorphisation of Zirconolite}

\author{
K.L. Smith, M.G. Blackford, G.R. Lumpkin \\ Materials Division \\ Australian Nuclear Science and Technology Organization \\ P.M.B.1, Menai, NSW 2234, AUSTRAILIA
}

Nestor J. Zaluzec

Materials Science Division, Kinetics \& Irradiation Effects Group

Argonne National Laboratory

9700 S. Cass Ave., Argonne, IL 60439 USA

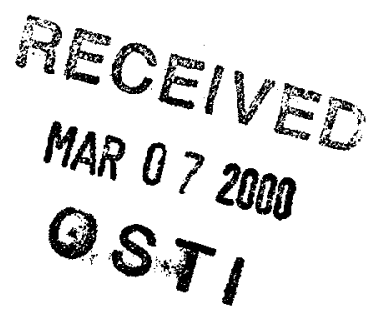

Symposium QQ Scientific Basis for Nuclear Waste Management XXIII, MRS Fall Meeting 1999, Boston, USA, November 29 - December 30, 1999.

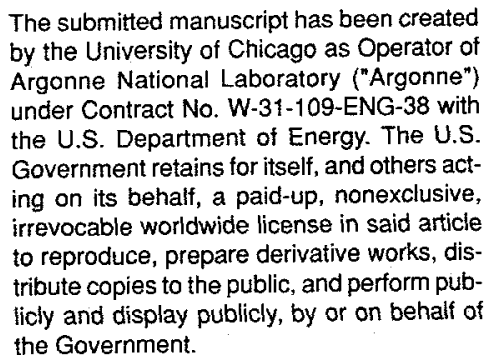

This work was supported by the U.S. Department of Energy, Office of Science Division of Materials Sciences, under contract \#W-31-109-ENG-38. 


\section{DISCLAIMER}

This report was prepared as an account of work sponsored by an agency of the United States Government. Neither the United States Government nor any agency thereof, nor any of their employees, make any warranty, express or implied, or assumes any legal liability or responsibility for the accuracy, completeness, or usefulness of any information, apparatus, product, or process disclosed, or represents that its use would not infringe privately owned rights. Reference herein to any specific commercial product, process, or service by trade name, trademark, manufacturer, or otherwise does not necessarily constitute or imply its endorsement, recommendation, or favoring by the United States Government or any agency thereof. The views and opinions of authors expressed herein do not necessarily state or reflect those of the United States Government or any agency thereof. 


\section{DISCLAIMER}

Portions of this document may be illegible in electronic image products. Images are produced from the best available original document. 


\title{
TEMPERATURE DEPENDENCE OF ION IRRADIATION INDUCED AMORPHISATION OF ZIRCONOLITE
}

\author{
K.L. Smith*, M.G. Blackford*, G.R.Lumpkin* and N.J. Zaluzec ${ }^{\dagger}$ \\ * Materials Division, Australian Nuclear Science and Technology \\ Organisation, P.M.B. 1, Menai, NSW 2234, AUSTRALIA. \\ * Materials Science Division, Argonne National Laboratory, 9700 South Cass \\ Ave, Argonne, Il 60439, USA
}

\section{INTRODUCTION}

Zirconolite is one of the major host phases for actinides in various wasteforms [1] for immobilising high level radioactive waste (HLW). Over time, zirconolite's crystalline matrix is damaged by $\alpha$-particles and energetic recoil nuclei recoil resulting from $\alpha$-decay events. The cumulative damage caused by these particles results in amorphisation. Data from natural zirconolites suggest that radiation damage anneals over geologic time and is dependant on the thermal history of the material [2]. Proposed HLW containment strategies rely on both a suitable wasteform and geologic isolation. Depending on the waste loading, depth of burial, and the repository-specific geothermal gradient, burial could result in a wasteform being exposed to temperatures of between $100-450^{\circ} \mathrm{C}$. Consequently, it is important to assess the effect of temperature on radiation damage in synthetic zirconolite.

Zirconolite containing wasteforms are likely to be be hot pressed at or below $1473 \mathrm{~K}$ $\left(1200^{\circ} \mathrm{C}\right)$ and/or sintered at or below $1623 \mathrm{~K}\left(1350^{\circ} \mathrm{C}\right)$ [3]. Zirconolite fabricated at temperatures below $1523 \mathrm{~K}\left(1250^{\circ} \mathrm{C}\right)$ contains many stacking faults [4]. As there have been various attempts to link radiation resistance to structure $[5,6,7]$, we decided it was also pertinent to assess the role of stacking faults in radiation resistance.

In this study, we simulate $\alpha$-decay damage in two zirconolite samples by irradiating them with $1.5 \mathrm{MeV} \mathrm{Kr}{ }^{+}$ions using the High Voltage Electron Microscope-Tandem User Facility (HTUF) at Argonne National Laboratory (ANL) and measure the critical dose for amorphisation $\left(D_{c}\right)$ at several temperatures between 20 and $773 \mathrm{~K}$. One of the samples has a high degree of crystallographic perfection, the other contains many stacking faults on the unit cell scale. Previous authors proposed a model for estimating the activation energy of self annealing in zirconolite and for predicting the critical dose for amorphisation at any temperature [8]. We will discuss our results and earlier published data in relation to that model.

\section{EXPERIMENTAL PROCEDURE}

Two zirconolite samples, were prepared via the alkoxide route [9]. One was hot-pressed at $1473 \mathrm{~K}\left(1200^{\circ} \mathrm{C}\right)$ for 2 hours (1200 sample) and the other was sintered at $1723 \mathrm{~K}\left(1450^{\circ} \mathrm{C}\right)$ for 1 week (1450 sample). TEM specimens were prepared by crushing material under ethanol then passing holey carbon grids through the suspension and collecting fine particles on the carbon film. All girds were cleaned in an Ar plasma for 5 min. using a South Bay PC 150 plasma cleaner. Zirconolite is not the sole phase present in the fabricated material. Therefore the positions of zirconolite grains on grids were mapped on secondary electron images (SEIs). In situ ion irradiation of the TEM specimens was performed using a $1.2 \mathrm{MeV}$ modified Kratos/AEI EM7 electron microscope (operated at $300 \mathrm{kV}$ ) interfaced with a NEC ion accelerator in the HVEM-Tandem User Facility at Argonne National Laboratory. At all temperatures apart from room temperature, temperature variation was no more than $3 \mathrm{~K}$. At room temperature, the temperature was $302 \mathrm{~K}$ during HVEM examination and rose to $328 \mathrm{~K}$ during ion irradiation. Grains selected for ion irradiation showed many maxima in their selected area electron diffraction (SAD) patterns. Specimens were irradiated with $1.5 \mathrm{MeV} \mathrm{Kr}^{+}$ions using the procedure described by Smith et al. [10]. For each monitored grain, between 8 and 20 negatives were taken at incremental doses. The average of the dose at which all Bragg reflections had disappeared and the dose immediately prior to that dose was taken to be the critical dose for amorphisation, $D_{c}$.

\section{RESULTS}

The 1450 sample basically has the zirconolite-2M polytype structure with a high level of crystallographic perfection. The 1200 sample also predominantly has the zirconolite-2M polytype structure but contains many stacking faults and twins on the scale of the unit cell. In spite of this 
difference in microstructure, the temperature dependence of the critical dose for amorphisation is similar for both samples shows (see figures 1 and 2). $D_{c}$ is almost constant up to temperatures near the critical temperature for amorphisation $T_{c}$ (above which recrystallisation is complete over the entire cascade volume), then it rises rapidly.

According to current theory [8], the temperature dependence of the amorphisation dose $D_{3}$ can be expressed by the following equation

$$
D_{c}=\frac{D_{o}}{1-\exp \left[\frac{E_{a}}{k}\left(\frac{1}{T_{c}}-\frac{1}{T}\right)\right]}
$$

where $D_{c}$ is the critical dose for amorphisation, $D_{0}$ is the amorphisation dose extrapolated to $0 \mathrm{~K}, \mathrm{E}_{\mathrm{a}}$ is the activation energy for self annealing, $T_{c}$ is the critical temperature above which recrystallisation is complete over the entire cascade volume, $k$ is Boltzmann's constant and $T$ is temperature ( $T$ and $T_{c}$ are in degrees Kelvin). A least squares analysis of our experimental data according to this equation yields the broken curves shown in figures 1 and $2, E_{i}$ values $0.14 \pm 0.04$ and $0.15 \pm 0.06 \mathrm{eV}$ and $\mathrm{T}_{c}$ values $637 \pm 22$ and $680 \pm 27 \mathrm{~K}$ for the 1200 and 1450 samples respectively. The $E_{a}$ and $T_{c}$ values of the 1200 and 1450 samples are the same within experimental error.

\section{DISCUSSION}

S.X. Wang et al. [11] measured the critical dose of $1 \mathrm{MeV} \mathrm{Kr}^{+}$ions for amorphisation of six zirconolites of various compositions and state that their data for end-member zirconolite $\left(\mathrm{CaZrTi}_{2} \mathrm{O}_{7}\right)$ indicate a two stage dependence. However, their contention hinges on the reliability of only one data point, the datum at $375 \mathrm{~K}$. Unfortunately S.X. Wang et al. [11] do not show error bars or give an estimation of the reliability of their data points. Our data may or may not support a two step dependence of $D_{c}$ on temperature. We will collect addtional data points and provide a full analysis in the extended paper.

White et al. [12] measured the critical dose of $1 \mathrm{MeV} \mathrm{Kr}+$ ions for amorphisation of zirconolite at 20,300 and $475 \mathrm{~K}$ and found it to be $7.1,10$ and 340 , in units of $10^{14}$ ions/cm $\mathrm{cm}^{2}$ respectively and from these data, they calculated an $E_{a}$ value of $0.129 \mathrm{eV}$. At any temperature, the $\mathrm{D}_{\mathrm{c}}$ values White et al. [12] measured are much greater than both ours and those of S.X. Wang [6]. The reasons why White et al. [12] measured such large critical dose values are not clear and are exacerbated by the fact that White et al. [12] did not estimate their errors.

Clinard [13] found that radiation damage induced swelling in Pu-substituted zirconolite and that the final volume depended on the temperature at which samples were stored (not on total storage time). At room temperature and $575 \mathrm{~K}$, Pu-substituted zirconolite specimens swelled by to 5 and 4 percent respectively, while at $875 \mathrm{~K}$ specimens showed $<0.5$ percent swelling even after 600 days. In agreement with the findings of Clinard [13], the $\mathrm{T}_{c}$ values calculated both in this study and by S.X. Wang et al. suggest that self annealing will occur at temperatures at approximately $650 \mathrm{~K}$.

Fabrication temperature and/or stacking fault disorder does not significantly affect the response of end-member zirconolite to radiation damage. This result is significant, if it holds for bulk samples, because it is anticipated that titanate wasteforms will be hot pressed at or below $1473 \mathrm{~K}\left(1200^{\circ} \mathrm{C}\right)$ and/or sintered at or below $1623 \mathrm{~K}\left(1350^{\circ} \mathrm{C}\right)$. Consequently the constituent zirconolite in wasteforms will contain many stacking faults.

\section{ACKNOWLEDGEMENTS}

The authors are grateful to Mike Colella for assistance in producing STEM maps of specimens and Sammy Leung for SEM data. The authors also thank the HVEM-Tandem Facility staff at Argonne National Laboratory for assistance during ion irradiations, in particular we thank Charlie Allen, Ed Ryan, Stan Ockers, Tony McCormick, Pete Baldo and Lauren Funk. The Facility is supported as a User Facility by the U.S. DOE, Basic Energy Sciences, under contract W-31-109-ENG-38.

\section{REFERENCES}


[1] R.C. Ewing, W.J. Weber and F.W. Clinard Jnr., "Radiation Effects in Nuclear Waste Forms for High Level Radioactive Waste," Progress in Nuclear Energy, 29 [2], 63-127 (1995)

[2] G.R. Lumpkin, K.L. Smith, M.G. Blackford R. Giere and C.T. Williams (1998) The crystallineamorphous transformation in natural zirconolite: evidence for long-term annealing, Mat. Res. Soc. Symp. Proc., 506, 215-222.

[3] A. Jostsons, E.R. Vance and B. Ebbingaus (1999) Immobilisation of surplus plutonium in titanate ceramics, presented at Global'99 "Nuclear Technology - Bridging the Millenia", Jackson Hole, Wyoming, USA, Aug29 - Spet 31999.

[4] E.R. Vance, C.J. Ball, M.G. Blackford, D.J. Cassidy and K.L. Smith (1990) Crystallisation of zirconolite from an alkoxide precursor, J. Nuc. Mater., 175, p.58-66.

[5] P.K. Gupta, Rigidity, connectivity and glass-forming ability, J. Am. Ceram. Soc., 76950, 10881095 (1993)

[6] L.W. Hobbs, A.N. Seeram, C.E. Jesurum and B.A. Berger, Structural freedom, topological disorder, and the irradiation-induced amorphisation of ceramic structures, Nuc. Instruments and Meths. in Phys Res., B116, 18-25 (1996)

[7] S.X. Wang, L.M. Wang and R.C. Ewing, Amorphisation of $\mathrm{Al}_{2} \mathrm{SiO}_{5}$ polymorphs under ion beam irradiation, Nuc. Instruments and Meths. in Phys. Res., B 127/128, 186-190 (1997)

[8] A. Meldrum, L.A. Boatner, W.J. Weber and R.C. Ewing (1998) Radiation damage in zircon and monazite, Geochimica et Cosmochimica Acta, 62, p. 2509-2520.

[9] A.E. Ringwood, S.E. Kesson, K.D. Reeve, D.M. Levins and E.J. Ramm (1988) Synroc, in "radioactive Waste Forms for the Future", eds W. Lutze and R.C. Ewing, Elsevier, p.233334.

[10] K.L. Smith, G.R. Lumpkin and N.J. Zaluzec (1997) In situ studies of ion irradiated zirconolite, pyrochlore and perovksite, J. Nuc. Materials, 250, 36-52.

[11] S.X. Wang, G.R. Lumpkin, L.M. Wang and R.C. Ewing (1999) Ion irradiation-induced amorphisation of six zirconolite compositions, in Radiation Effects in Insulators, REI-10, July 18-23, 1999, Jena, Germany

[12] T. J. White, H. Mitamura, K. Hojou and S. Furuno, Radiation stability of ceramic waste forms determined by in situ electron microscopy and He ion irradiation, Mat. Res. Soc. Symp. Proc. Vol. 333, 227-232 (1994).

[13] F.W. Clinard, Jnr. (1986) Review of self-irradiation effects in Pu-substituted zirconolite, Am. Ceram. Soc. Bull., 65, 1181-87.
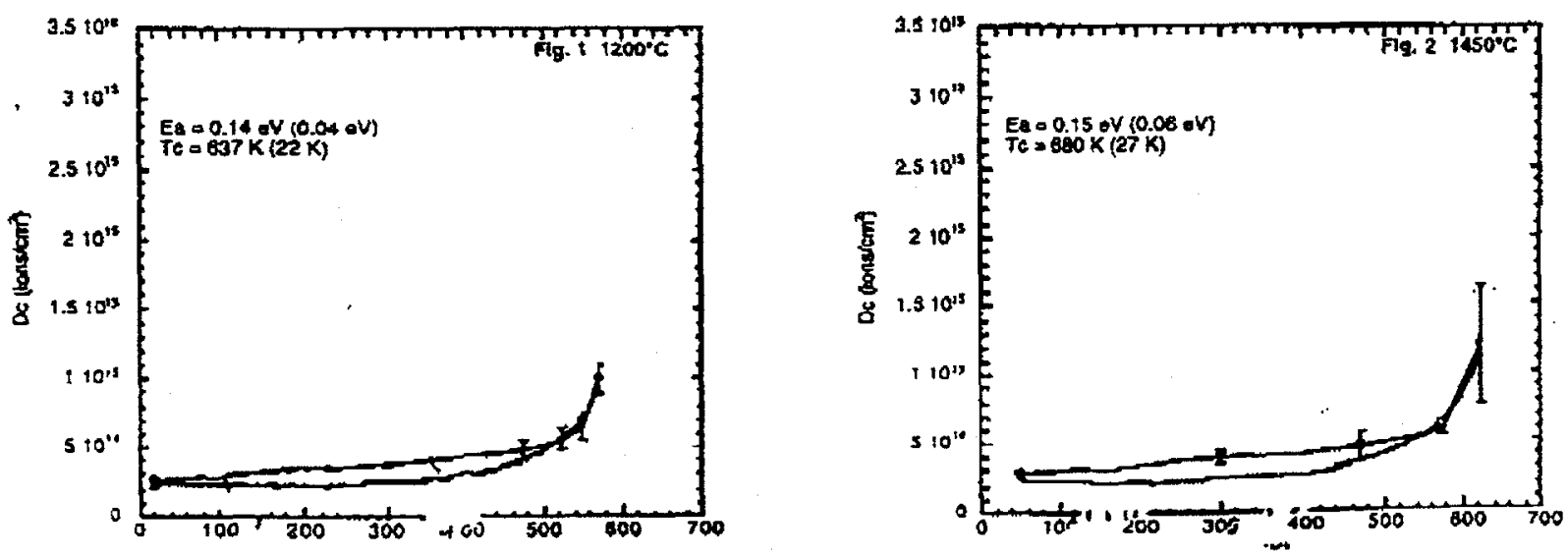

Figures 1 and 2 show De versus temperature data for 1200 and 1450 samples respectively. Dashed curves show least squares fits of data. 